\title{
A Study of Grammatical Case Forms and their Directionality in Fulfulde: The Transformational Generative Approach
}

\author{
Idris Muhammad Bello \\ University of Maiduguri \\ P.M.B. 1069, Bama Road, Maiduguri, Borno State, Nigeria \\ idrisbello2014@gmail.com
}

\begin{abstract}
Case Theory interacts with Government Theory in its operation and so, cases are assigned to the complements of governors. Case assigners are the governors of their dependent clauses while the case receivers are the governed NPs. So, the purpose of the study is to survey case assignment in Fulfulde generally by identifying and analysing the elements of Fulfulde structures and their relationship in terms of structural case. Unstructured observation was the method used for eliciting data for this study. Adequate and natural data were recorded and analysed sentence by sentence, the way they were uttered by the native speakers. The Theoretical Framework adopted for data analysis by this study is Principle and Parameters Theory. The study discovered that in Government, apart from (V)erbs, (P)repositions and tensed INFL, (N)ouns, (A)djectives and Focus Markers FMs can also govern and assign case to their complements in Fulfulde. The study has proved that in Fulfulde, cases can be assigned either to the left or to the right, depending on the relation.
\end{abstract}

Keywords: Case assignment, case form, Fulfulde, government, Principle \& Parameters Theory

\section{Article history:}

Received: 20.11.2020

Accepted: 08.01.2021

\section{For citation:}

Idris Muhammad Bello (2021). A Study of Grammatical Case Forms and their Directionality in Fulfulde: The Transformational Generative Approach. RUDN Journal of Language Studies, Semiotics and Semantics, 12(2), 514-525. doi: 10.22363/2313-2299-2021-12-2-514-525

(C) Idris Muhammad Bello, 2021

This work is licensed under a Creative Commons Attribution 4.0 International License https://creativecommons.org/licenses/by/4.0/ 
УДК 811.432.113’36

\title{
Трансформативный генеративный подход в исследовании грамматических падежных форм и их направленности в языке фула
}

\author{
Идрис Мухаммад Белло \\ Университет Майдугури \\ Р. М. В. 1069, Бама-роуд, Майдугури, штат Борно, Нигерия \\ idrisbello2014@gmail.com
}

\begin{abstract}
Аннотация. Цель исследования - представить общую картину падежных функций в языке фула (Fulfulde) путем идентификации и анализа элементов структур языка фула и их отношении к терминам структурного описания падежей. Описание уровня наблюдения стало основным методом сбора материала для исследования. Зафиксированный оригинальный и адекватный материал был проанализирован предложение за предложением с учетом их употребления носителями языка фула. В данном исследования теоретическая основа анализа материала обусловлена принципами параметрического описания. В ходе исследования было установлено, что теория управления наряду с глаголами $(\mathrm{V})$, предлогами $(\mathrm{P})$ и комплексом INFL, включающим имена (N), прилагательные (A) и фокус-маркеры (FM), в полной мере характеризует функции падежа языка фула относительно опорного слова в предложении. Исследование показало, что в предложении падежи распределяются в зависимости от характера синтаксической связи и отношения, как и позиции левого или правого распространителя опорного слова.
\end{abstract}

Ключевые слова: распределение падежей, падежная форма, язык фула (Fulfulde), теория принципов и параметров

История статьи:

Дата поступления: 20.11.2020

Дата приема в печать: 08.01.2021

\section{Для цитирования:}

Idris Muhammad Bello. A Study of Grammatical Case Forms and their Directionality in Fulfulde: The Transformational Generative Approach // Вестник Российского университета дружбы народов. Серия: Теория языка. Семиотика. Семантика. 2021. Т. 12. № 2. С. 514-525. doi: 10.22363/2313-2299-2021-12-2-514-525

Fulfulde $^{1}$

\section{Introduction}

In the cotemporary descriptive approach of linguistics, many studies have been carried out to describe different aspects of languages. One of the most important and interesting discoveries is the Universal Grammar (UG) which was put forward by

\footnotetext{
${ }^{1}$ Fulfulde is the language of the Fulbe (Fulah) which is spoken by more than 32 million people (see David, Simons and Charles [1]), and it is one of the languages of wider communication in many parts of West Africa. It is also spoken in some countries of North Africa, East Africa and Central Africa. The language is one of the African languages and one of the most widely spoken in West Africa sub-region (see Arnott [2], McIntosh, 1984, Breedveld, 1995, Bello [3] etc.).
} 
Chomsky (Cook, \& Newson [4]). UG refers to the grammatical categories, structures and rules that are common to all languages irrespective of family [5]. For instance, word classes such as nouns, verbs prepositions and movement rules can be considered linguistic universals; they are common in all languages. However, we also have the concept of Parameters where there are options for languages to opt to. These parametric differences allow languages to have different but common systems like head parameter, wh-question, null-subject etc. where there are options in any.

Therefore, it has been observed that in government and grammatical case assignment, some structures in Fulfulde do opt for an extra-ordinary structural relation. Verbs, Prepositions and Agreement are known as governors and case assigners to their complements, but in this language, structures different from these are common, so this study attempts to study grammatical case forms and their assignment in Fulfulde generally. In Fulfulde, morphological case is realised with a few nouns in the case of pluralisation, but pronouns have a kind of morphological case inherent in them. The morphological case which generally applies to pronouns, more especially the personal pronouns is presented on table 1 below.

The study aims at analysing case assignment in Fulfulde by investigating the composition of the linguistic elements in given structures of the language. Unstructured observation was used for data collection for this study. The data were analysed by studying the order of the words in any given utterance with the hope of finding out the relationship between individual words in a sentence. The sentences were first grouped according to their types, and then according to their constituents.

\section{Theoretical Framework}

Principle and Parameters Theory (henceforth PPT) is the one adopted for data analysis in this study. It is a theory developed from Chomsky's works, particularly [4]. It has three levels; the Logical Form, D-structure and S-structure related to each other by a single movement rule referred to as (move $\alpha$ ), (see Matthews [5]). PPT consists of sub-theories preferably called modules. Government is the relation that is obtained between the head and its complement. The verbs and prepositions are governors of their complement, while the subject is governed by the INFL when it contains AGR [6] while the notion of government is thematic based, its operation involves structural configuration (Ibid). Government is defined structurally as follows:

$\alpha$ governs $\beta$ if and only if $\alpha$ maximally c-commands $\beta$ (i.e $\alpha$ and $\beta$ share the same maximal projection), and no $\gamma, \gamma$ a barrier for $\beta$ such that $\gamma$ excludes $\alpha$. $\alpha$ is a governor if and only if $\alpha$ is an $\mathrm{X}^{0}$.

The above definition is formalised by Sells [7. P. 40] as cited in Yusuf [8. P. 142] as follows:

$\alpha$ governs $\beta$ iff

(a) $-\alpha$ c-commands $\beta$ and

(b). $\quad \alpha$ is an $\mathrm{X}^{0}$, i.e $\alpha \varepsilon\{\mathrm{N}, \mathrm{V}, \mathrm{P}, \mathrm{A} . \mathrm{I}\}$ 
Case Theory interacts with Government Theory in its operation, because cases are assigned to the constituents of governors. The Case Theory, $\theta$-Theory and the government theory all have a common operational ground for the structures of their relevant constituents. Case assigners are the governors of their dependent clauses while the case receivers are the governed NPs. Case assignment is controlled by a principle known as Case Filter which states that every phonetically realised [NP] must be assigned case [6]. Though every grammatically acceptable structure may have case assigners for all its NPs at the D-Structure level, at the S-Structure, there are constructions that have more NPs than the said governors, yet they are considered grammatical by the native speakers.

PPT is concerned with the relationship of elements in a given structure, such as verbs and prepositions to their complements. However, there are some verbs that do not need complements. The intransitive verbs like sleep, die, cry may not need an NP as a complement. However, what draws more attention in such structures includes double object construction and verbs such as believe. In Fulfulde, the non-verbal sentences pose a similar problem to proper government and structural case assignment.

\section{Discussion about Case Assignment in Fulfulde}

When we talk about grammatical case assignment, we mean the abstract or structural Case, but, morphological case is discussed first because there are elements of morphological case in the language, especially, the personal pronouns. However, Fulfulde is not a morphological case language.

\section{Elements of Morphological Case in Fulfulde}

Fulfulde does not generally mark morphological cases on the nouns ${ }^{2}$, but it marks pronouns. Fulfulde distinguishes the different case forms of pronoun according to their case-positions, though some are still overlapping in form. The pronouns can be categorised into Nominative, Emphatic, Accusative and Genitive case forms. Let us study the table below:

Table I

\section{Categories of personal pronouns in Fulfulde}

\begin{tabular}{|l|l|l|l|l|}
\hline Persons & Subject & Focus & Object & Genitive \\
\hline $\mathbf{1}^{\text {st }}$ Pers. Sing. & mi & miin & yam & am \\
\hline $\mathbf{1}^{\text {st }}$ Pers. PI inclusive & en & enen & en & meeden \\
\hline $\mathbf{1}^{\text {st }}$ Pers. PI exclusive & min & minin & (a)min & amin \\
\hline $\mathbf{2}^{\text {nd }}$ Pers. Sing. & a & aan & maa & maada \\
\hline $\mathbf{2}^{\text {nd }}$ Pers. PI & on & onon & on & moodon \\
\hline $3^{\text {rd }}$ Pers. Sing & o & kanko & mo & maako \\
\hline $3^{\text {rd }}$ pers. PI & 6e & kambe & be & mab.6e \\
\hline
\end{tabular}

Adapted from [3]

\footnotetext{
${ }^{2}$ Languages that mark morphological case have different forms of a given noun depending on the Case position the noun occupies. Latin and Arabic are examples of languages with morphological case forms such as nominative, accusative, dative, locative, genitive, ablative, allative, etc. depending on the language in question (see Blake [10]).
} 
If we study the above table of pronouns carefully, we shall find out that Fulfulde maintains relative forms of morphological case assignment. Though some of the lexical items are flexible, all the four case forms mentioned above are represented in the table above. At least, the first-person singular, the second person singular, and the third person singular pronouns distinguish all the four case forms. In English, the regular pluralisation of nouns by adding ' $\mathbf{s}$ ' simply indicates morphological case [9]. So, there are similar instances of morphological case in Fulfulde as well. But generally speaking, plural formation in Fulfulde is very complex, because it involves two important grammatical processes known as Noun Class System (NCS) and Initial Consonant Alternation (ICA). Notwithstanding, there are some simple nouns that illustrate clear instances of inflection which may be regarded as morphological case in their plural formation. Let us consider the table below.

Table II

Fulfulde morphological case

\begin{tabular}{|l|l|l|l|}
\hline S/No. & Singular & Plural & Gloss \\
\hline i & boor-o & boor-ooji & bag \\
ii & suk-a & suk-aabe & boy \\
iii & laam-do & laam-be & king \\
iv & ndiyam & ndiyam-ji? & water \\
v & cuf-u & cuf-i & mosquito \\
\hline
\end{tabular}

If you observe the examples in the table above, (i, ii, and iv) are inflected by addition of a suffix to the morpheme in the process of pluralisation, while in (iii and v), the final segment(s) are substituted to realise the relevant inflections. Therefore, these nouns and the few others of their type are typical examples of morphological case realised inflectionally in the language.

\section{Structural Case Assignment in Fulfulde}

The second type of case is the abstract Case which is realised structurally based on principles of government. In fact, this study is more interested in the abstract Case assignment which is syntactically realised than the morphological case which is restricted to certain forms. However, the morphological case has been discussed to clarify and solidify the background of case in Fulfulde generally. The structural Case is discussed below as abstract Case which is concerned with the relationship of heads and their complements based on the position they occupy. E.g.

1. [IP Bakari [vp res-i deft-e mum [pp dow daag-o]]].

Bakari res-i deft-e mum dow daag-o

\footnotetext{
${ }^{3}$ The question marker (?) put against the plural form of ndiyam 'water' means it is controversial. The classical plural form is di'eele, while ndiyamji is semantically extended to mean 'hard drink'. However, all of the younger speakers and most of the older speakers if not all today, use the word ndiyamji as the plural form.
} 
Bakari put-PAST book-CM his on mat-CM

'Bakari put his books on a mat.'

2. [Fp Bakarii on [IP $\mathrm{t}_{\mathrm{i}}$ ] [vp res-i deft-e mum [pp dow daag-o]]]

Bakari on res-i deft-e mum dow daag-o.

Bakari FM put-PAST book-CM his on mat-CM

'Bakari put his books on a mat'

If we analyse sentence (1) above, we shall find out that it has three governors. The V, the P and the AGR. The verb res 'put' governs its complement NP defte mum 'his books' and assigns ACC Case to it, while the preposition dow 'on' as the governor of the NP daago 'mat' assigns an OBL Case to it on one hand. On the other hand, the morpheme $-i$ that follows the verb res is a past tense marker ${ }^{4}$. Therefore, the subject of the sentence Bakari which is an NP receives its Case from the tensed INFL. Sentence (2) is different from (1) in only one element, i.e., the focus marker (FM) on. In this case, the FM is the case assigner to its specifier which is the subject of the sentence. The sentence in example (2) is derived from that of (1) by movement. The subject moved away from the specifier position of IP to the specifier position of the focus phrase FP. Therefore, the INFL assigns NOM. Case to the trace $[\mathrm{t}$ ] of the moved NP, while the NP that lands at the SPEC-FP is assigned EMPH Case by the FM. The assignment is illustrated further on the tree diagram analysis of the sentence in example (1) as we can see below.

3.

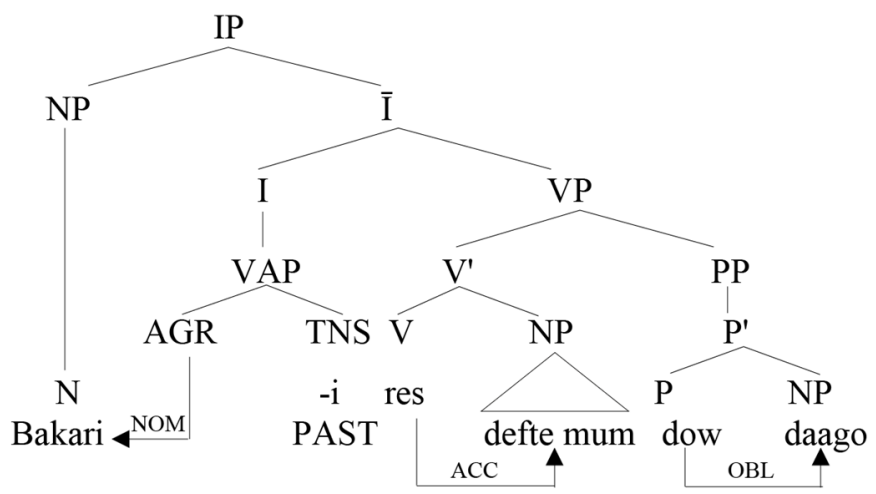

'Bakari put his books on a mat.'

According to Chomsky [6] the AGR governs and assigns NOM Case to the subject NP, the V governs and assigns objective Case to its dependent NP, and preposition assign Oblique Case to its governed NP, while NP is assigned a genitive case in the configuration [NP - X-bar]. Though dative construction is possible,

\footnotetext{
${ }^{4}$ Fulfulde is a language that derives most of its words through suffixation. The Fulfulde verbs are described by three parameters, viz; Voice Aspect and Polarity (VAP). Voice of a verb can be active, middle or passive. The aspect takes care of the tense which is divided into two; completive and incompletive, while the polarity determines whether the verb is positive or negative. There is a set of suffixes for each voice and each suffix is a morpho-semantic entity. Each voice has future, conditional future, present, past, negative past and negative future tense markers respectively (see Arnott [2], Mukoshy [11], McIntosh, 1984 \& Bello [3]).
} 
a double object construction is resorted to instead. Therefore, in the configuration [VP $\mathrm{V} \mathrm{NP}^{1} \mathrm{NP}^{2}$ ], the second $\mathrm{NP}$ is assigned case inherently as determined by properties of its [-N] governor [6]. Let us consider the examples below.

4. Nenne sorr-i mbaala.

Nenne sell-PAST sheep

'Nenne sold a sheep.'

5. Julde res-i deft-e dow daago.

Julde put - PAST book-CM on mat

'Julde put books on a mat.'

6. Julde hokk-i Saali ceede.

Julde give-PAST Saali money

'Julde gave Saali some money.'

Number 7-9 below is a tree diagram analysis of the above sentences. The arrows indicate the cases as well as the relation of the Case assigners and the Case receivers. In the tree diagram in (7) below, the AGR assigns NOM Case to the external argument, i.e.; the subject, while $\mathrm{V}$ as the governor of its complement NP and assigns ACC Case to it.

7.

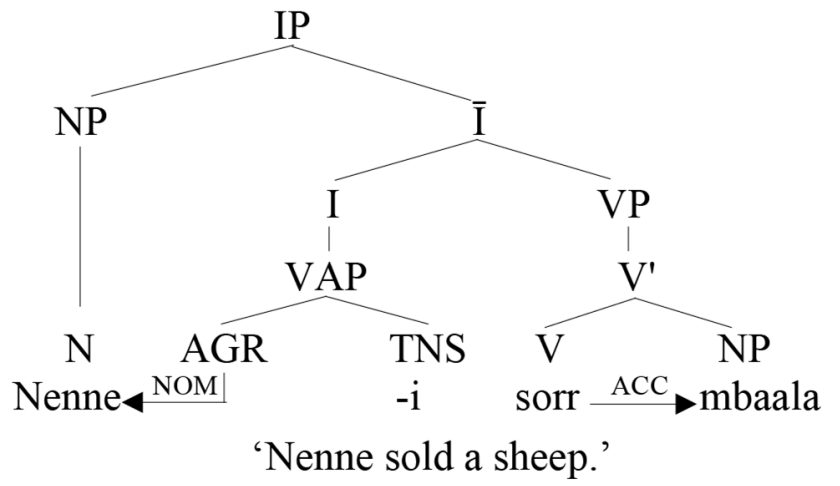

It is illustrated in the tree diagram below also, that V assigns ACC Case to its complement but in addition, there is also a $\mathrm{P}$ which also assigns OBL Case to its complement.

8.

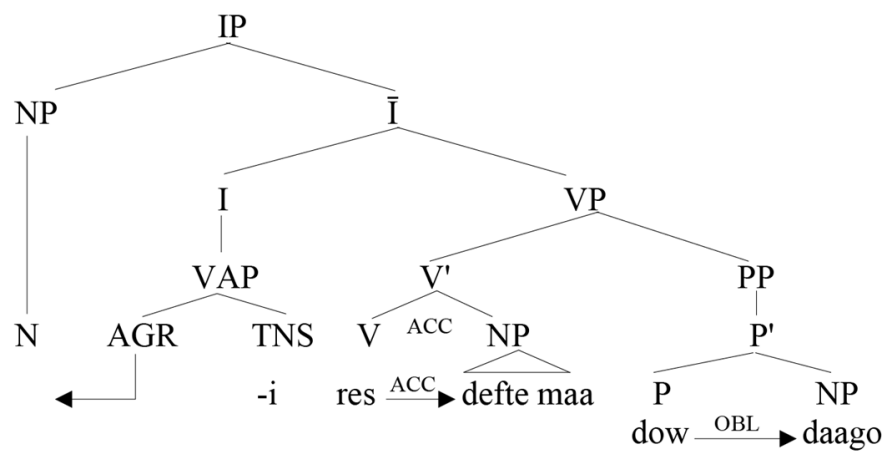

'Julde put your books on a mat.' 
In the example (9) below, there are obviously two NPs as complements of the $\mathrm{V}$ hokki 'gave' which poses a little problem. However, one form of case is common to all of the three diagrams, that is the Nominative NOM case which is assigned by the AGR to the subjects of the sentences as external arguments.

9.

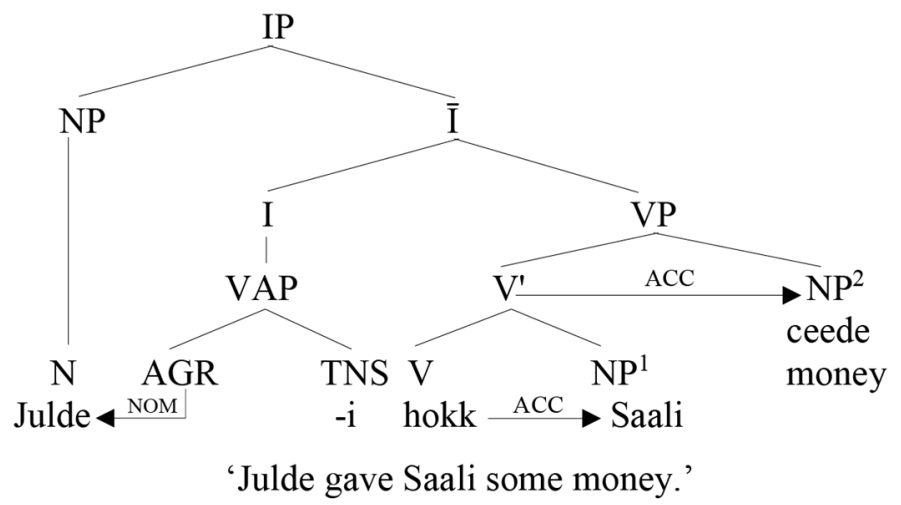

In example (9) above, the second NP cannot receive case from the $\mathrm{V}$ because there is a barrier between the $\mathrm{NP}^{2}$ and $\mathrm{V}$ as a governor. Though they are sharing the same maximal projection VP, the first NP as a barrier rules it out from being governed by the $\mathrm{V}$, therefore, cannot assign case to it. However, according to [6], it is case-marked inherently, by the $\mathrm{V}$ at the D-Structure before dative alternation in the case of English (see Sanusi [12]). A better alternative that fits Fulfulde data where dative construction is not common is the suggestion by Chomsky [6], in which he deals with double object construction and argues that the second NP of this type of constructions receives structural Case from the $\mathrm{V}^{\prime}$ while the first NP receives structural case from the $\mathrm{V}$.

\section{Exceptional Case Marking and the Non-verbal Constructions of Fulfulde}

In every rule there is an exception. That is why we have exceptional case marking in English. According to Riemsdijk \& Williams [13. P. 234], "English infinitives can have lexical subjects in certain exceptional circumstances... in the approach that excludes case theory." For instance, the verb believe poses problem in English.

The grammaticality of a construction can also be determined by the application of case assignment, hence the need for Case Filter. Case Filter is a principle of Case Theory which controls the grammaticality of a sentence by ensuring that all overt NPs are assigned case by case assigners [4]. V, P and tensed INFL are identified as the case -assigners in English. It is well argued that nouns do not assign case in English. However, construction such as (10) below poses problem in the analysis.

10. (a) I believe him to be rich.

(b) *My belief him to be rich. 
(c) *My belief of him to be rich.

In Fulfulde, the non-verbal structures or sentences pose a similar problem to the proper government. The study proposes that such structures to be perceived as clauses one subordinate to the other. The left NP to be the main clause and governs the NP on the right as its complement, so that in the configuration [NP-NP, AP-NP or NP-AP] the left [-X head of the] XP which inherently incorporates the auxiliary and eliminates the verb of the sentence, governs the NP or AP on the right and assigns case to it.

This is in conformity to Chomsky's suggestion that Nouns and Adjectives do assign case (see Chomsky [4]). This is empirically confirmed or ascertained by the non-verbal sentence constructions in Fulfulde where we can have a series of NPs, AP and NP, and so on as a sentence or main clause without any form of verb in the structure. For instance:

11. Hannde mi Laamdo.

Today I king

'Today I am a king.'

12. Halima nyawdo.

Halima sick

'Halima is sick.'

13. Ballo jamo.

Ballo well

'Ballo is well.'

The constructions in the above examples have no overt verbs, yet the sentences are grammatical as far as the native speakers of the language are concerned. The first constituent of (11) has no definite position, because it is an Adjunct, and can be adjoined either at the initial or final position of a sentence because it is mobile. The remaining constituents are both NPs. The first NP can be a noun, a pronoun or an adjective in which case it can be called AP. Let us consider the following diagram.

14.

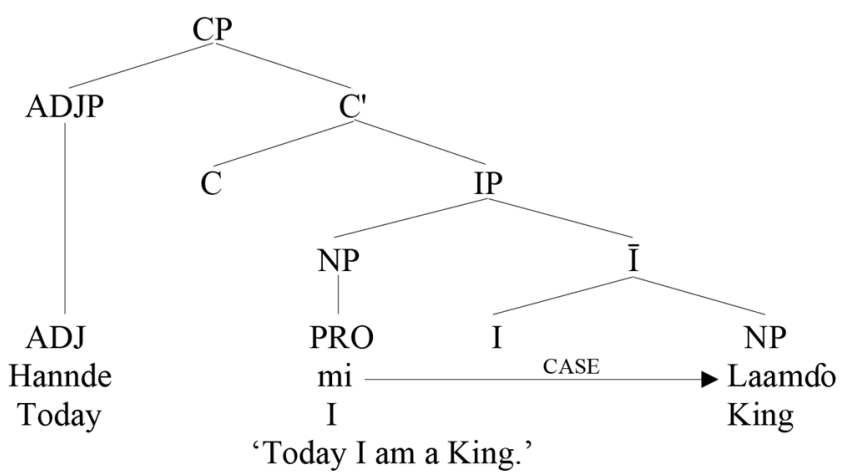

If we look at the relation between the NPs, it is clear that the conditions required by case assignment are met in the above structure: Structural Relationship; the need for a governor to be a lexical item; the m-command and adjacency 
principles are met by the construction, and above all it is a native speaker grammatically approved structure.

One can substitute the pronoun $m i$ in the above sentence with a noun such as Buuba 'personal name' and/or an Adjective such as Bodeejo 'the red' (in complexion) without affecting the grammaticality of the sentence. Therefore, we can conclude that in Fulfulde, Adamawa Fulfulde in particular, in addition to verbs, prepositions and Agreement that assign case in English, Nouns, pronouns, and Adjectives too can assign Case to their dependent NPs. Moreover, the Sanusi's [12. P. 67], argument that "Structural Case is assigned at S-Structure and does not necessarily involve any thematic relation between the assigner and the assignee" can be in favour of our argument here.

The case assignment of such Fulfulde structures can be treated under the same condition with the double object construction in English where the second NP is said to receive inherent Case from the main verb at the D-Structure before the dative alternation [12]. Since the alternative of the same structure with a verb can possibly be accepted by the native speaker, we can propose D-Structures from which this type of sentences are derivable. For instance:

15. Hannde mi wart-i laamdo.

Today I become-PAST king

'Today I have become a king.'

It can be assumed that the case is assigned inherently by the verb at D-Structure before the elimination of the verb. Since the verb disappears completely from the structure, it seems logical for the adjacent element $m i$ ' $\mathrm{I}$ ' which is a pronoun here to inherit the Case assigned by the verb at the D-Structure to its complement laamdo 'a king' to the right which is a noun, because such a structure, i.e., a non-verbal sentence does not have tensed INFL, therefore, has no Case to receive but assigns the ACC Case inherited from the verb to its complement to fulfil the structural obligations. All being well for the argument, the study assumes that the Case assigned by these elements in such non-verbal sentences is conditioned by the adjacency.

\section{Directionality of Fulfulde Case Assignment}

In Fulfulde Case assignment, ACC case is assigned to the right while the nominative case which is assigned to the external argument by the AGR is assigned to the left [6], and the FM assigns Case to the focused NP to the left, which is called emphatic Case [14].

In the case of focus constructions, Bayere [14] argues that in Yorùbá: "When the object NP is moved to the SPEC of the FP, it is assigned a different case while the trace retains its accusative Case assigned to it originally." So, the NP that is focused and moved receives an emphatic Case which is assigned by the FM to the NP on the left. So, also in Fulfulde, Verbs and Prepositions assign ACC Case to their complements to the right while AGR assign nominative Case to the subject or its trace to the left, and the focus marker too assigns emphatic Case to the SPECFP to the left as well. Let us consider the examples below. 
16. [FP e [IP Adamu [vp janngin-i be]]]

Adamu janngin-i be.

Adamu teach-PAST them

'Adamu taught them.'

17. [FP Adamui on [IP $t_{i}[\mathrm{vP}$ janngin-i be]]].

Adamui on $t_{i}$ janngin-i be.

Adamu FM teach-PAST them

'It is Adamu that taught them.'

For more clarification, let us illustrate (17) above on a tree diagram. The subject of the sentence Adamu which was the SPEC-IP, as the external argument was assigned NOM Case by the AGR. When it was focus and moved to the SPECFP, it receives EMPH Case from the focus, while its trace at the SPEC-IP still receives the NOM Case as illustrated in the tree diagram below:

18.

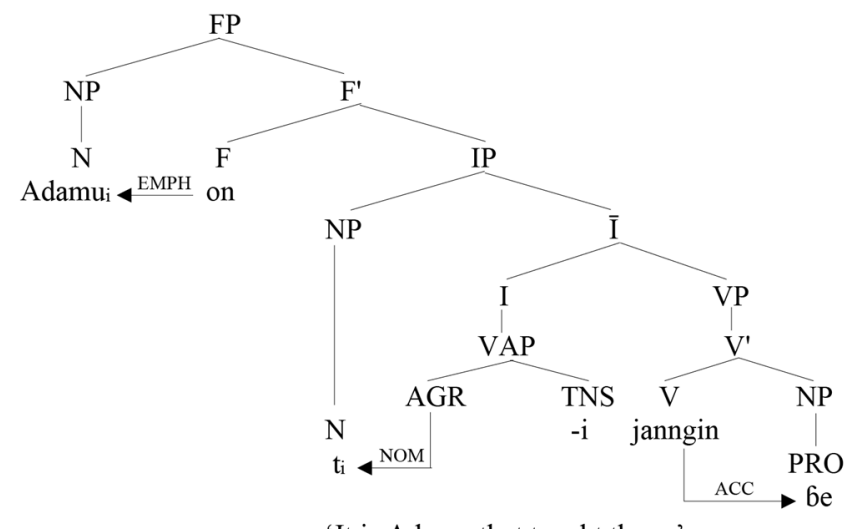

'It is Adamu that taught them.'

All the arrows in the tree diagrams indicate the directions of the Case assignment. Both accusative and oblique case forms are assigned to the complements of verbs and prepositions respectively to the right, while emphatic and nominative Case forms are assigned to the SPEC-FP and its trace at the SPECIP respectively.

\section{Conclusion}

This paper studies aspect of Case assignment in Fulfulde generally by investigating the elements of Fulfulde sentences and their relationship in terms of case assignment and its directionality. Though verbs and prepositions have been known as governors and case assigners, in Fulfulde, there are non-verbal sentences that pose problems to the analysis of such structures. The observation and the analysis carried out proved that apart from the common case assigners: Verbs, Prepositions and Agreement, in Fulfulde, Nouns and Adjectives can also govern and assign structural Case to their complements. The study shows further that Verbs, Prepositions and Nouns assign Case to their complements to the right, while AGR and FM assign Case to the specifiers of IP and FP respectively to the left. 


\section{References}

1. David, E.M., Simons, G.F. \& Charles. D.F. (eds.) (2020). Ethnologue: Languages of the world. Dallas, Texas: SIL International. URL: https://www.ethnologue.com/language/ful on 15/01/2021 (accessed: 10.12.2021).

2. Arnott, D.W. (1970). The Nominal and Verbal Systems of Fula Oxford: Clarendon.

3. Bello, I.M. (2016). 'A Study of Focus Construction in Fulfulde: The Case of Adamawa Dialect' M.A. Thesis submitted to the Department of Linguistics and Nigerian Languages, University of Ilorin.

4. Cook, V.J. \& Newson, M. (2007). The Chomsky's Universal Grammar. Malden: Blackwell.

5. Matthews, P.H. (2007). Oxford Concise Dictionary of Linguistics. Oxford: Oxford University Press.

6. Chomsky, N. (1993). Lectures on Government and Binding: The Pisa Lectures. (7th ed). Berlin: Mouton de Gruyter.'

7. Sells, P. (1985). Lectures on Contemporary Syntactic Theories. Menlo Park: CSLI.

8. Yusuf, O. (1998). Fundamentals of Syntax and the Study of Nigerian Languages. Ijebu-Ode: Shebiotimo Publications.

9. Fakuade, G. (2012). English Grammar for Schools \& Colleges. (7th ed.) Ilorin: Haytee Press and Publishing Company.

10. Blake, B.J. (2001). Case. Cambridge: Cambridge University Press.

11. Mukoshy, I. (1977). Fulfulde Suffix Morphophonemic Changes. Harsunan Najeriya. A Journal of Centre for the Study of Nigerian Languages, Bayero University, Kano. VII, $1-22$.

12. Sanusi, I.O. (2001). The Syntax of Double Object Constructions in Batonu. PhD Thesis submitted to the Department of Linguistics and Nigerian Languages, University of Ilorin.

13. Riemsdijk, H.V. \& William, E. (1986). Introduction to the Theory of Grammar. Cambridge: The MIT Press.

14. Bayere, B.E. (2004). Aspects of Focus Construction in Owe: Government-Binding Approach. M.A. Thesis submitted to the Department of Linguistics and Nigerian Languages. Ilorin: University of Ilorin.

\section{Information about the author:}

Idris Muhammad Bello, a lecturer and Level Coordinator in the department of Languages and Linguistics, and Assistant Faculty Representative in Senate Committee on course system, University of Maiduguri; has Master degree in Linguistics and is a PhD. candidate in General Linguistics, and he specialises in Fulfulde syntax. Research interest: syntax, phonology and morphology; e-mail: idrisbello2014@gmail.com

\section{Сведения об авторе:}

Идрис Мухаммад Белло, $\mathrm{PhD}$ (лингвистика), преподаватель кафедры языкознания и лингвистики Университета Майдугури, представитель факультета в Сенатском комитете Университета Майдугури; специализируется на синтаксисе языка фула. Сфера научных интересов: синтаксис, фонология и морфология; e-mail: idrisbello2014@gmail.com 